\title{
Polycentric Model of Development of Partner Relations as an Instrument of Development of the Russian Federation's Regions
}

\author{
Daria Vyacheslavovna Kadatskaya ${ }^{1 *}$, Yury Ivanovich Seliverstov ${ }^{1}$, Elena Aleksandrovna Nikitina ${ }^{1}$, Svetlana \\ Petrovna Gavrilovskaya ${ }^{1}$
}

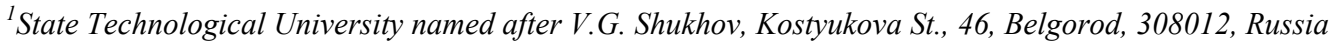

*Corresponding author E-mail: kadatskaya.d.v@mail.ru

\begin{abstract}
The search for new drivers for the development of the Russian Federation's regions from the point of view of innovative transformations is currently relevant. In the current economic conditions, the role of the higher school in the training of demanded personnel is growing. Today, the university can and should become a reliable integrator of the business environment with state and municipal authorities. For the consortium of business environment, state authorities and universities, today there are significant barriers due to lack of infrastructure, good legal support, transparency of communication, sources of financing, etc. In order to optimize this process, the paper proposes the AUB polycentric partnership model, which will ensure free entry to and exit from the consortium, attracting the maximum number of participants, taking into account the elimination of possible risks.
\end{abstract}

Keywords: Development; Model; Partnership; Region.

\section{Introduction}

The development and establishment of new economic formations, the introduction of the project approach into practice makes it possible for the university to become a strategic center for the generation of innovative developments, information flows, and human resources.

The development of a three-level model for the development of the regional economy has already contributed to the formation of the polycentric model for the development of regional agglomeration. The model today includes the following levels:

Level 1 - Authorities (A);

Level 2 - University (U);

Level 3 - Business (B).

The prerequisites for creating such a model can include (Figure 1):

- formation of an innovative cluster of regional economic development;

- introduction of project management in business structures;

- improvement of the image of higher education institutions through the implementation of state development programs.
Prerequisites for creating the three-level AUB model
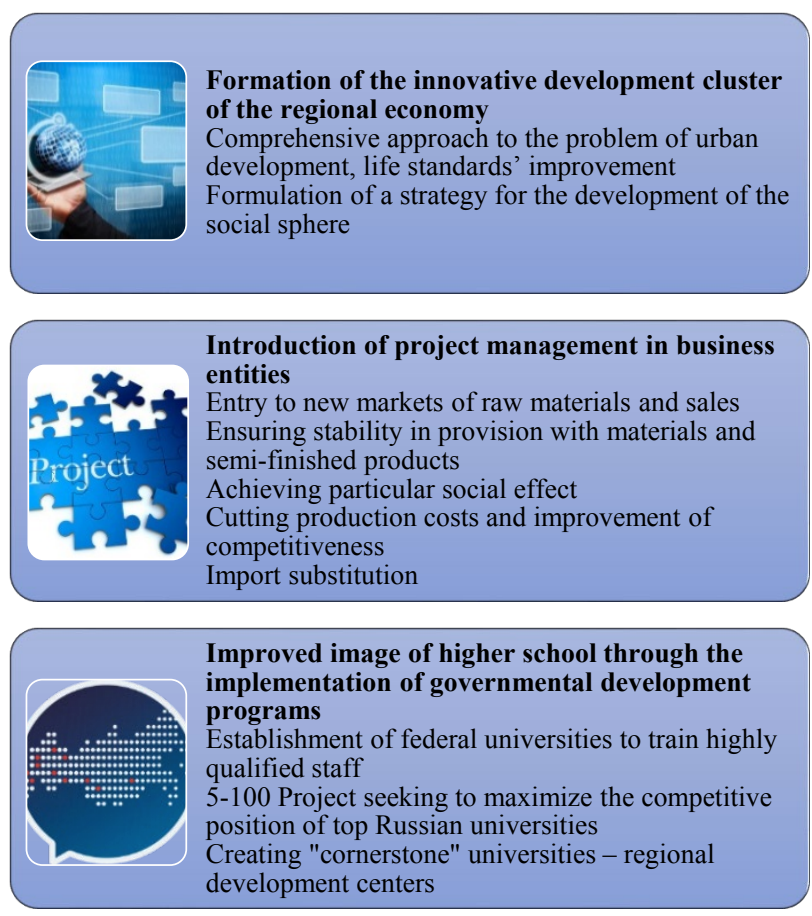

Fig. 1: Prerequisites for creating the AUB model

The current trend in the development of the regional economy contributes to the emergence of the educational sphere to a new level, which will make it possible to determine the university not only from the position of the educational institution, but also from the position of a special entrepreneurial structure. 


\section{Problem Statement}

The program of creation and development of basic universities in Russia is aimed at creating university centers for innovative, technological and social development of regions on the basis of which business partnerships are created. Already today, both legislative and organizational and managerial prerequisites have been created in the Russian Federation for educational budget and autonomous institutions to become founders of small innovative enterprises (SIE) being companies and business partnerships, the activities of which consist in the practical application (introduction) of the results of intellectual activity [1]. The Ministry of Education and Science of the Russian Federation has created an interactive information system "Register and Monitoring of Small Innovative Enterprises in the Scientific and Educational Sphere", which keeps records of notifications about the establishment of SIE, forms a register of notifications for further submission of data on payment of insurance premiums to the control bodies, and performs general monitoring of SIE [2]. Figures 2-3 show the dynamics of the establishment of business entities in 2009-2018, as well as the distribution of the creation of commercial companies (business partnerships) in the federal districts.

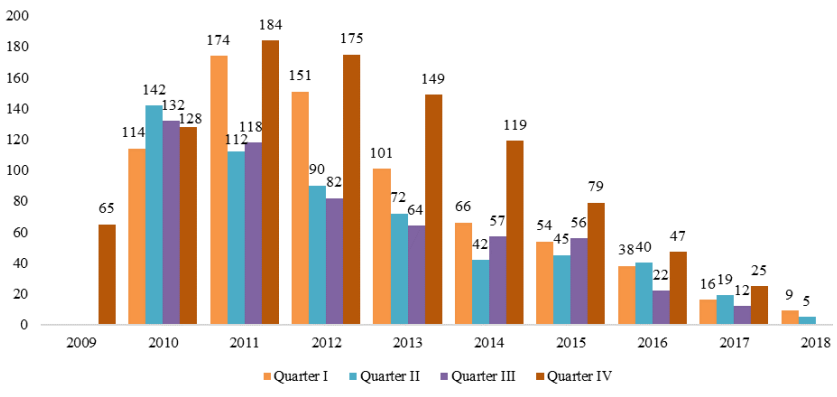

Fig. 2: Dynamics of the establishment of business entities in 2009-2018

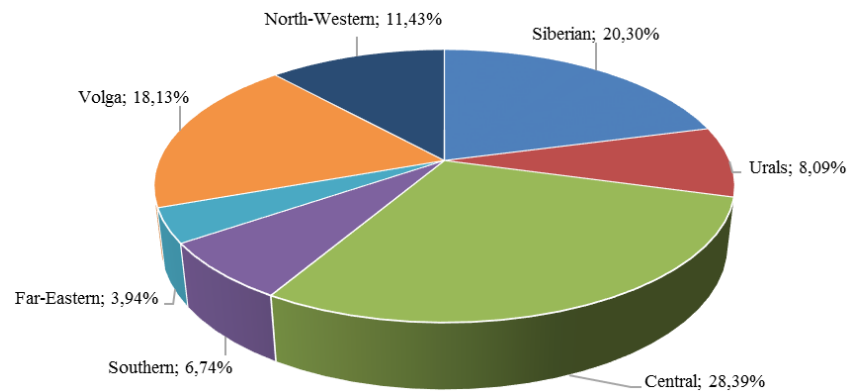

Fig. 3: Distribution of the creation of commercial companies (business partnerships) in the federal districts

\section{Research Questions}

The analysis of the statistical data of the registration of notifications on the establishment of SIE showed that the number of SIE that were created decreased over time. This suggests that the number of founders is limited and has now reached saturation in the generation of new SIE. Therefore, new tools and new incentives for innovative activity of universities and scientific organizations are needed. In the authors' opinion, the program for the development of "cornerstone" universities in Russia will solve a number of problems. A "cornerstone" university will provide an innovative platform for interaction of small and medium-sized businesses with potential new highly skilled personnel, and will also promote the development of state projects, enabling to concentrate financial resources for self-financing [3].

\section{Purpose of the Study}

The creation of the polycentric model for developing partnerships between higher education institutions with the business environment and public authorities (the AUB model) will provide innovative, scientific and personnel support for protecting the geopolitical and economic interests of the regions through the creation of a system of continuous professional education, integration of education, science and production, as well as strategic partnership with the business community (Figure 4).

The subjects of the partnership model are the three strong points of the region's development: public authorities, university and business environment.

The partnership model includes 5 levels that cover various stages of the processes [4]. The public authorities act in the proposed model as the customer and represent a regional technological platform covering various clusters: construction, transport and logistics, mining and metallurgy, IT, engineering, biopharmaceutical, social, etc. In addition, the public authorities act as a focal point, providing normative regulation of the process of integration of the model's subjects.

The business community is represented by entrepreneurial structures of various levels (large enterprises, small and medium businesses), with the main task to increase competitiveness through the use of innovative technologies. Entrepreneurial structures, integrating with the university, on the one hand, provide themselves with highly qualified personnel, and, on the other hand, they receive new technologies.

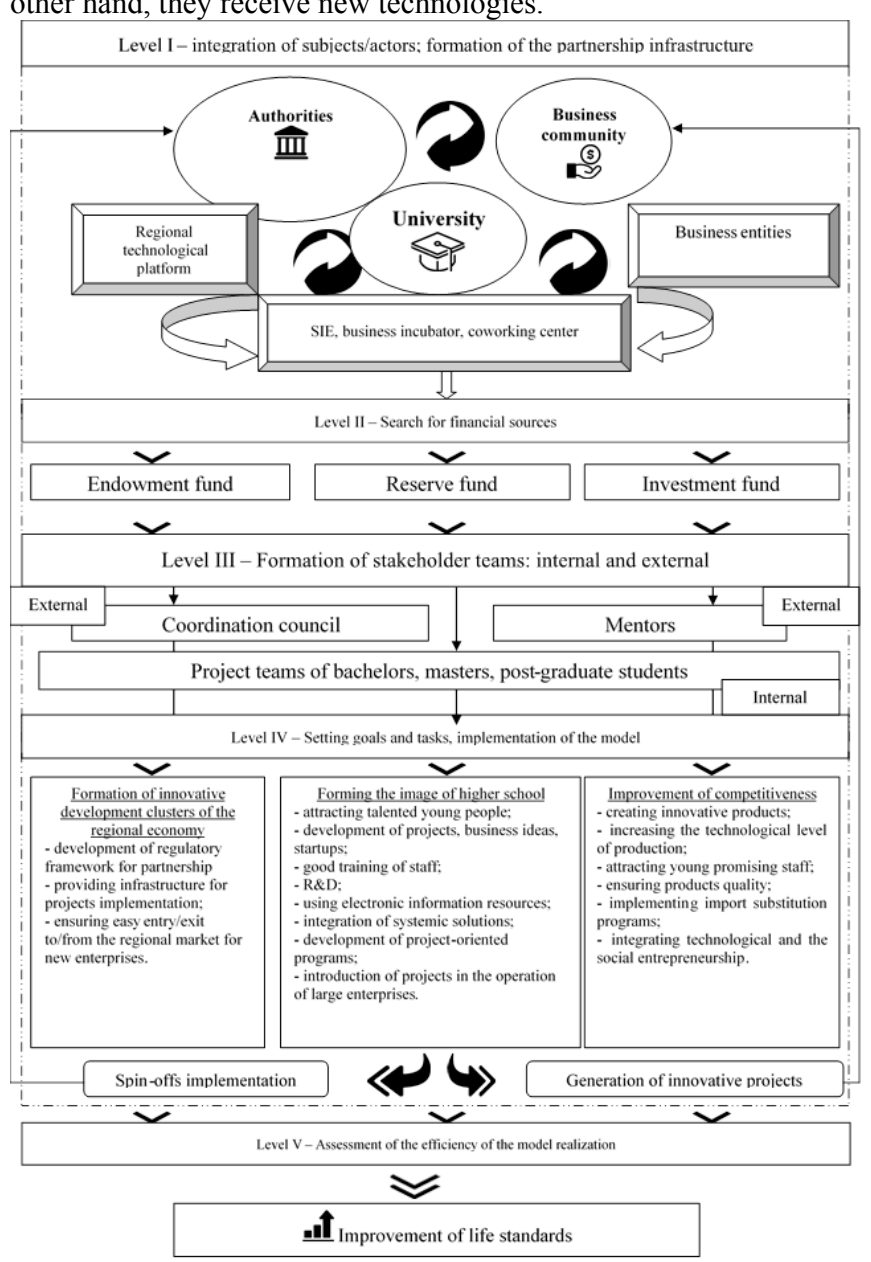

Fig. 4: The AUB polycentric model of partnership

At the second level of the model, sources of funding are being formed: state endowment funds are created by the public authorities, investment fund is created by the business community 
by merging financial flows from entrepreneurial structures, and in universities, financial flows are pooled into a reserve fund.

The next stage of the partnership model goes into the formation of operating teams, management bodies, coordination and control over the implementation process.

\section{Methods}

The partnership model contributes to the achievement of various goals and objectives from the perspective of three actors: public authorities are tasked with ensuring the regulatory and legislative framework for the integration process; universities solve the task of developing innovative products, technologies, business ideas, implementation and application of innovations in the operational process of their enterprises. If the model is successfully integrated into the goals and objectives set, not only a solution in the field of technology projects can be formed on the basis of universities, but also independent new business structures of the spin-off format that need to ensure access to the regional market can be created [6]. At the output from this model, a synergetic effect is obtained from the integration of the interaction of the actors. Thus, on the part of the public authorities, a new level of quality of life is taking shape, the emergence of innovative technologies, new clusters of development of economic sectors occurs [7]. The business community acquires at the output of the integration model some new technological products, personnel reserve of young specialists maximally adapted to the conditions of the enterprise's functioning, through the system of integrated training of personnel in combination of theoretical training with practical training at the basic enterprises and through participation in the implementation of projects; rethinking the organization of labor of employees, increasing the effectiveness of their work.

\section{Results}

For universities, integration will create a certain image that will affect the contingent of future students, will enable to unite talented university students with entrepreneurial abilities, develop unique interdisciplinary competencies; create a methodological and educational basis for the development and implementation of social entrepreneurship projects, increase students' level of emotional intelligence and empathy [8].

\section{Conclusion}

For the implementation of the partnership model, a number of barriers have now emerged, such as:

- the difficulty of involving students in the process of participation in entrepreneurship, lack of desire, lack of initiative;

- unformed legislative framework for regulating the relationships among model participants;

- lack of a clear source of investment;

- backlog of teachers in the urgency of the development of the business environment;

- motivation of entrepreneurship and its involvement in the process;

- evaluation of the effectiveness of the final indicators;

- an ecosystem for implementing this model [9].

The implementation of the partnership model will provide a communication and analytical and entrepreneurial tool aimed at the formation of joint research and development programs, the creation of promising commercial technologies, new products (services) for the development of the regional economy.

\section{Acknowledgement}

The paper is published within the framework of the strategic development program of BSTU named after V.G. Shukhov.

\section{References}

[1] Turko TI, Ivanov BV, Khramov NB, Fedorkov VF, Dukvits SV \& Fakhurdinov OV (2016), Informatsionno-analiticheskoe obespechenie ucheta malykh innovatsionnykh predpriyatii, sozdannykh v sfere obrazovaniya i nauki [Informational and Analytical Support of Accounting for Small Innovative Enterprises Established in the Sphere of Education and Science]. Innovatika $i$ ekspertiza 2(17), 51-57.

[2] Scientific Research Institute - Federal Research Centre for Projects Evaluation and Consulting Services (2018), Uchet $i$ monitoring malykh innovatsionnykh predpriyatii nauchno-obrazovatelnoi sfery [Accounting and Monitoring of Small Innovative Enterprises of the Scientific and Educational Sphere]. https://mip.extech.ru/index.php

[3] Materialy mezhvuzovskogo foruma "Opornye universitety draivery razvitiya regionov" [Materials of the Interuniversity Forum "Cornerstone Universities - Drivers of Regional Development"]. Belgorod, 2017. http://bstuforum2017.ru/program

[4] Elkina VN (2014), Formy i modeli partnerskikh otnoshenii organov vlasti i biznes-soobshchestva $\mathrm{v}$ innovatsionnykh proektakh [Forms and Models of Partnership Relations between Government Bodies and the Business Community in Innovative Projects]. Izvestia OSA 1(45), 207-211.

[5] Nikitina EA (2013), Vzaimosvyaz pokazatelya konkurentosposobnosti predpriyatiya i konkurentosposobnosti tovara [Correlation of the Competitiveness of the Enterprise and Competitiveness of Goods]. Vestnik Belgorodskogo gosudarstvennogo tekhnologicheskogo universiteta im. V.G. Shukhova 4, 125-128.

[6] Seliverstov YI (2013), The Analysis of Intellectual Property Use in the Economic Turnover of Russian Enterprises. World Applied Sciences Journal 25(12), 1763-1769.

[7] Haken G, Sinergetika [Synergetics]. Moscow: Mir, 1980.

[8] Khadiullina GN (2010), Transformatsiya intellektualnoi sobstvennosti v sovremennoi rossiiskoi ekonomike [Transformation of Intellectual Property in the Modern Russian Economy]. Vestnik Kazanskogo yuridicheskogo instituta MVD Rossii 1, 97-100.

[9] Khubiev KA (2012), Innovatsionnaya ekonomika i genezis novykh otnoshenii [Innovational Economy and the Genesis of New Relations]. Ekonomist 3, 62-67. 